\title{
Edukasi Pencegahan Virus Corona (COVID-19) dan Donasi Masker untuk Kesehatan Masyarakat di Kelurahan Jati, Kota Padang
}

\author{
Azrimaidaliza, Septia Pristi Rahmah, Nadia Chalida Nur, Novia Wirna Putri, dan Siti Nur Hasanah \\ Fakultas Kesehatan Masyarakat, Universitas Andalas, Kampus Limau Manis, Padang, 25163. Indonesia \\ E-mail: azrimaidaliza@ph.unand.ac.id
}

Keywords:

COVID-19,

education,

leafleat, mask

donate, poster

Kata Kunci:

COVID-19, donasi masker, edukasi, leafleat, poster

\begin{abstract}
COVID-19 cases in West Sumatra have shown a significant increase in the past month. To accelerate the handling of COVID-19, the government implemented Large-Scale Social Restrictions started on April 22, 2020. Enforcement is also carried out in Padang which has the highest number of COVID-19 cases with 107 positive confirmed cases with 12 deaths. Efforts to prevent the spread of this virus can be carried out through collaborative community service activities between educational institutions and urban villages in Padang City. One of these activities was community service activities held in Jati, East Padang District, Padang City, namely through educational activities using leafleat and posters as promotion media then also donating masks to improve people's healthy behavior. Promotional media were distributed to the public due to situations that make it impossible to carry out activities by gathering many people in one place. The activity went well, received a good response from the village head and all village officials. Media and donations were distributed by the village head especially for poor families and low access to information. Monitoring and evaluation were needed from the village and service providers in increasing the implementation of healthy behavior by the community.
\end{abstract}
ABSTRAK
Kasus COVID-19 di Provinsi Sumatera Barat menunjukkan peningkatan jumlah yang cukup signifikan dalam satu bulan terakhir. Untuk mempercepat penanganan COVID-19, maka pemerintah Provinsi Sumatera Barat menerapkan Pemberlakuan Pembatasan Sosial Berskala Besar (PSBB) per tanggal 22 April 2020. Pemberlakuan juga dilaksanakan di Kota Padang yang memiliki kasus COVID-19 paling tinggi dengan jumlah kasus terkonfirmasi positif sebesar 107 kasus dengan 12 kematian per tanggal 1 Mei 2020. Upaya pencegahan menyebarnya virus ini dapat dilakukan melalui kerjasama kegiatan edukasi antara institusi pendidikan dengan kelurahan yang ada di Kota Padang. Salah satu kegiatan tersebut adalah kegiatan edukasi di kelurahan binaan di Jati, Kecamatan Padang Timur, Kota Padang yaitu melalui kegiatan edukasi menggunakan media promosi leafleat dan poster kemudian juga pemberian atau donasi masker untuk meningkatkan perilaku sehat masyarakat. Media promosi dibagikan kepada masyarakat dikarenakan situasi yang tidak memungkinakan untuk melaksanakan kegiatan dengan mengumpulkan masyarakat banyak dalam satu tempat. Kegiatan berjalan dengan lancar, mendapatkan sambutan yang baik dari Lurah dan semua perangkat kelurahan. Media dan donasi didistribusikan oleh pihak kelurahan ke RT/RW terutama diperuntukkan bagi keluarga yang tidak mampu dan akses informasi rendah. Perlu monitoring dan evaluasi dari pihak kelurahan dan tim dalam meningkatkan penerapan perilaku sehat oleh masyarakat. 


\section{PENDAHULUAN}

Pada Desember 2019 dilaporkan adanya kasus pneumonia yang tidak biasa di Wuhan, Provinsi Hubei, China. Kasus pertama ditemukan di Kota Wuhan, dicurigai berasal dari pasar ikan di kota ini, namun sumber pasti penularannya belum diketahui dengan pasti. Tidak butuh waktu yang lama, penyakit ini telah menyebar dengan cepat di berbagai provinsi lain di China, dan negara lainnya seperti di Thailand, Jepang, dan Korea Selatan. Pada tahun 2019 virus ini dinamai dengan Novel Coronavirus (2019-nCoV). Pada 11 Februari 2020 penyakit ini dinamai Coronavirus Disease (COVID-19) oleh WHO. Penyakit ini disebabkan oleh virus Severe Acute Respiratory Syndrome Coronavirus-2 (SARS-CoV-2). Virus ini menyebar dengan cepat di China dan 190 negara lainnya, salah satu penyebab virus ini cepat terlular adalah dikarenakan virus dapat ditularkan dari manusia ke manusia (1).

Peningkatan kasus COVID-19 terus terjadi di China sejak ditemukannya kasus pertama. Puncak penyakit ini terjadi sekitar bulan Januari sampai dengan awal Februari tahun 2020. Kasus terbanyak dilaporkan datang dari Hubei pada awalnya tersebar, yang kemudian disusul dengan provinsi-provinsi lain dari seluruh China. Terdapat sebanyak 7.736 kasus yang terkonfirmasi COVID-19 di China pada 30 Januari 2020. WHO mengumumkan COVID-19 sebagai penyakit pandemic pada 12 Maret 2020. Tercatat 175.825 jumlah kematian yang tersebar di 213 negara/kawasan di dunia (1).

Pada 2 Maret 2020 Indonesia melaporkan kasus COVID-19 pertama yang berjumlah dua kasus. Kasus ini berlanjut dan telah dikonformasi terdapat 1.528 kasus dan 136 kasus kematian pada 31 Maret 2020. Indonesia menjadi negara dengan tingkat mortalitas tertinggi di Asia Tenggara dengan persentase kasus sebesar 8,9\%. Data terbaru pada tanggal 23 April 2020 kasus terkonfirmasi positif sebanyak 7.775 kasus dengan 647 kematian(2). Penyebaran virus ini semakin agresif karena manusia tertular virus dari manusia lainnya. Transmisi SARS-CoV-2 dari pasien simptomatik terjadi melalui droplet yang keluar saat batuk atau bersin(1).

Bersadarkan saran WHO, Indonesia ditetapkan sebagai negara darurat corona, oleh karena itu pemerintah mengambil beberapa langkah yang ditetapkan sebagai kebijakan untuk pencegahan penularan COVID-19 ini. Pemerintah membuat beberapa kebijakan yang diberlakukan di seluruh daerah sebagai upaya antisipasi dan menurunkan angka kejadian penyakit ini. Kebijakan yang diberlakukan antara lain yaitu membatasi aktifitas diluar rumah, merumahkan segala kegiatan persekolahan, bekerja dari rumah (work from home), dan melakukan kegiatan beribadah di rumah. Kebijakan ini tentunya sudah dianalisa dan dipertimbangkan dengan sebaik-baiknya agar dapat meminimalisir masalah yang terjadi di masyarakat ${ }^{(3)}$.

Selain itu Pemerintah juga menetapkan kebijakan karantina wilayah dengan menutup beberapa akses jalan dalam kurun waktu tertentu, pembatasan jumlah transportasi, pembatasan jam operasional transportasi, yang bertujuan untuk membatasi aktifitas masyarakat diluar rumah. Kebijakan karantina wilayah ini dinamai dengan PSBB yaitu Pembatasan Sosial Berskala Besar(3).

Di Provinsi Sumatera Barat kasus COVID-19 menunjukkan jumlah yang cukup signifikan dalam satu bulan terakhir. Hal ini dikarenakan Sumatera Barat telah menjadi pusat aktivitas dan mobilitas masyarakat yang sangat tinggi. Selain itu, penyebaran kasus telah menggambarkan adanya sub-cluster dan transmisi lokal. Jumlah kasus COVID-19 di Sumatera Barat per tanggal 23 April 2020 adalah sebanyak 86 kasus dengan 9 kematian(4).

Melihat kasus COVID-19 yang terus mengalami peningkatan, pemerintah Provinsi Sumatera Barat juga menerapkan PSBB yang terdapat dalam Keputusan Gubernur Sumatera Barat Nomor 180-297-2020 tentang Pemberlakuan Pembatasan Sosial Berskala Besar di Wilayah Provinsi Sumatera Barat Dalam Rangka Percepatan Penanganan COVID-19(4). Salah satu kota di Provinsi 
Sumatera Barat dengan kasus COVID-19 tertinggi adalah Kota Padang dengan jumlah kasus terkonfirmasi positif sebesar 53 kasus dengan 8 kematian per tanggal 23 April 2020. Kota Padang juga sudah menerapkan PSBB berdasarkan keputusan dari Gubernur Sumatera Barat terhitung tanggal 22 April 2020 sampai dengan 14 hari ke depan(4).

Kelurahan Jati merupakan salah satu kelurahan di Kota Padang dan merupakan kelurahan binaan Fakultas Kesehatan Masyarakat Universitas Andalas. Daerah ini berada di Timur Kota padang dengan jumlah masyarakat yang cukup padat serta memiliki latar belakang penduduk yang bervariasi. Berdasarkan data yang diperoleh, Kelurahan Jati merupakan kelurahan dengan kasus COVID-19 cukup tinggi yaitu sebanyak 5 kasus per tanggal 23 April 2020(4).

Permasalahan ditemukan di masyarakat adalah masih banyak yang belum paham pencegahan penularan COVID-19 ini diantaranya pentingnya menggunakan masker ketika keluar rumah, pentingnya personal hygiene, cuci tangan pakai sabun, dan pyshical distancing. Bukanlah hal yang mudah untuk menjadikan Perilaku Hidup Bersih dan Sehat (PHBS) sebagai kebiasaan masyarakat. Diperlukan pemahaman dan motivasi dari individu itu sendiri sehingga setiap individu lebih disiplin dalam menerapkannya. Untuk itu penyampaian informasi melalui kegiatan edukasi kepada masyarakat diperlukan untuk meningkatkan pengetahuan masyarakat. Salah satu pelaksanaan kegiatan edukasi kepada masyarakat dapat berupa Komunikasi Informasi dan Edukasi (KIE) yaitu penyuluhan yang diberikan kepada individu maupun kepada masyarakat ${ }^{(5)}$.

Berdasarkan permasalahan tersebut, maka Tim Edukasi Layak Anak Kelurahan jati tertarik mengangkat topik "Edukasi Pencegahan Virus Corona (COVID-19) dan Donasi Masker untuk Kesehatan Masyarakat di Kelurahan Jati, Kota Padang", yaitu melakukan edukasi masyarakat dengan memberikan edukasi dan promosi kesehatan mengenai pencegahan penularan COVID-19 melalui media leafleat dan poster tentang pencegahan COVID-19 dan donasi masker kepada masyarakat di Kelurahan Jati. Kegiatan bertujuan untuk meningkatkan pengetahuan masyarakat mengenai COVID-19 dan sebagai bentuk antisipasi terhadap penyebaran COVID-19 yang merupakan ancaman kesehatan global pada saat ini. Kegiatan edukasi dilaksanakan dengan menggunakan leafleat dan poster sebagai media promosi yang kemudian dibagikan kepada masyarakat dan ditempel di beberapa tempat strategis. Masker yang didonasikan diberikan untuk keluarga kurang mampu yang tersebar di Kelurahan Jati.

\section{METODE}

Kegiatan dilaksanakan melalui beberapa tahapan, meliputi : (1) Perencanaan, (2) Pelaksanaan, dan (3) Monitoring dan Evaluasi. Kegiatan direncanakan berlokasi di Kelurahan Jati sebagai salah satu kelurahan binaan Fakultas Kesehatan Masyarakat Universitas Andalas. Selama ini kegiatan yang dilaksanakan di kelurahan binaan berupa kegiatan layak anak, sehat dan pencegahan stunting. Kemudian dengan adanya pandemi COVID-19 maka kegiatan diarahkan pada upaya pencegahan penularan virus corona (COVID-19) yang akan berisiko juga pada kelompok rentan seperti anak.

Kegiatan ini berupa persiapan proposal kegiatan mencakup identifikasi kegiatan yang dilaksanakan di kelurahan binaan layak anak, yaitu kelurahan Jati, Kota Padang. Kegiatan ini dikaitkan dengan situasi pandemi COVID-19. Selain itu, persiapan materi, berupa leafleat dan poster untuk kegiatan edukasi. Dalam kegiatan persiapan materi, dilaksanakan penelusuran referensi mengenai COVID-19 yang dicantumkan pada leafleat dan poster serta pencantuman nama media sosial (instagram) sebagai media komunikasi dengan masyarakat. Selanjutnya media tersebut dicetak sesuai dengan kebutuhan di kelurahan. Disamping itu, pembelian masker untuk didonasikan kepada masyarakat terutama diperuntukkan bagi keluarga yang tidak 
mampu sebanyak 200 kepala keluarga yang tersebar di RT/RW yang ada di kelurahan Jati. Dalam perencanaan juga dipersiapkan teknis penyerahan media kepada lurah melalui komunikasi dengan lurah termasuk waktu yang tepat menyerahkan media dan donasi sesuai dengan kesediaan lurah beserta perangkat kelurahan. Hal ini termasuk yang perlu dipersiapkan karena situasi pandemi COVID-19 dan akan diterapkannya PSBB sehingga dalam kegiatan nantinya

"Edukasi Pencegahan Virus Corona (COVID-19) dan Donasi Masker untuk Kesehatan Masyarakat" diangkat menjadi tema kegiatan edukasi ini. Tim edukasi diterima langsung oleh Lurah, Sekretaris Lurah dan juga disaksikan oleh aparat Kelurahan Jati di Kantor Kelurahan Jati. Kegiatan yang dilakukan berupa edukasi dengan menggunakan media leafleat dan poster sebagai alat promosi kesehatan yang diserahkan kepada Lurah dan kemudian leafleat didistribusikan kepada masing-masing RW atau RT. Sedangkan poster dipasang di tempat-tempat strategis yang mudah dilihat oleh masyarakat seperti di kantor kelurahan dan di RW/RT.

Kegiatan monitoring dan evaluasi dilaksanakan melalui pemantauan oleh tim edukasi masyarakat kelurahan layak anak FKM Unand terkait proses distribusi leafleat, pemasangan poster di tempat-tempat umum dan distribusi masker kepada masyarakat di kelurahan Jati. Pemantauan dengan cara mengkonfirmasi kepada Lurah pada hari berikutnya dan juga melalui informasi yang diperoleh dari masyarakat Kelurahan Jati. Melalui kegiatan ini diharapkan pengetahuan dan pemahaman masyarakat meningkat dan mau menerapkan perilaku pencegahan COVID-19 dalam kehidupan sehari-hari. Hal ini dapat diketahui dari penggunaan masker pada saat keluar rumah dan mencuci tangan dengan sabun serta membersihkannya dengan air mengalir atau menggunakan desinfektan pada saat pergi ke tempat-tempat umum.

\section{HASIL DAN PEMBAHASAN}

Kegiatan edukasi dilakukan dengan membagikan media leafleat dan poster juga disertai dengan pemberian donasi berupa masker sebanyak 400 buah telah dilaksanakan pada tanggal 20 April 2020 di Aula Kantor Lurah Jati. Tujuan kegiatan ini adalah untuk meningkatkan pengetahuan masyarakat mengenai COVID-19 dan sebagai bentuk antisipasi terhadap penyebaran COVID-19 yang merupakan ancaman kesehatan global pada saat ini. Kegiatan ini diterima dengan antusias oleh Pak Lurah dan aparat kelurahan. Pada saat kegiatan, Pak Lurah menyampaikan bagaimana kondisi masyarakat Kelurahan Jati terkait COVID-19, yaitu pada saat mulai merebaknya kasus ini di Kota Padang ditemukan salah satu anggota kelurahan terkena virus corona. Kasus tersebut terjadi dikarenakan yang bersangkutan merupakan salah satu tenaga medis yang bekerja di rumah sakit milik pemerintahan pusat yang berada di Kelurahan Jati.

Kegiatan edukasi melalui media leafleat dilaksanakan mengingat kondisi saat ini yang tidak memungkinkan kegiatan edukasi mengumpulkan orang dalam jumlah banyak. Media leafleat adalah salah satu media promosi kesehatan yang menyampaikan informasi atau pesan - pesan kesehatan melalui lembaran - lembaran lipat. Isi informasi dapat berupa kalimat atau gambar atau gabungan antara keduanya(6). Media leafleat yang dibagikan berisikan informasi mengenai definisi COVID-19, gejala-gejala yang dialami oleh pasien COVID-19 dan risiko yang akan terjadi apabila kondisi seseorang dalam kondisi buruk. Selain itu, media ini memuat informasi tentang upaya-upaya yang dapat dilakukan untuk mencegah dan meminimalisir penularan virus ini seperti menjalankan protokol kesehatan berupa memakai masker, jaga kebersihan diri salah satunya dengan selalu mencuci tangan dengan sabun dan air mengalir atau menggunakan handsanitizer setelah menyentuh permukaan benda, konsumsi makanan dengan gizi seimbang 
untuk meningkatkan imunitas tubuh, istirahat cukup dan olahraga rutin. Informasi yang disampaikan terkait COVID-19 antara lain bersumber dari Organisasi Kesehatan Dunia atau WHO dan Kementerian Kesehatan Indonesia. Dengan adanya penyampaian informasi melalui leafleat diharapkan pengetahuan masyarakat khususnya di Kelurahan Jati meningkat dan selanjutnya dapat menerapkan dalam kehidupan sehari-hari berupa upaya-upaya pencegahan agar tidak terkena COVID-19.

Media edukasi yang disiapkan selain leafleat adalah poster. Media yang disampaikan ini berisikan informasi seputar COVID-19 yang kemudian ditempel di tempat-tempat yang mudah dilihat dan dibaca oleh masyarakat. Poster ini salah satunya dipasang di Kantor Kelurahan Jati. Informasi tentang COVID-19 ini secara spesifik berisi apa yang dilakukan individu pada saat berada di fasilitas umum. Poster merupakan salah satu media promosi kesehatan dalam bentuk media cetak berisi pesan-pesan/informasi kesehatan yang biasanya di tempat-tempat umum(6). Kegiatan edukasi khususnya seputar COVID-19 diharapkan dapat dijalankan di semua wilayah. Kerjasama institusi pendidikan dan pemerintah daerah harus terus digalakkan dalam mengatasi permasalahan ini. Kontribusi institusi pendidikan dalam memberikan edukasi kepada masyarakat sangat besar sekali perannya melalui penggunaan media yang inovatif dan sesuai dengan kebutuhan masyarakat saat ini. Media edukasi yang dijelaskan dan diserahkan untuk masyarakat ada pada Gambar 1.

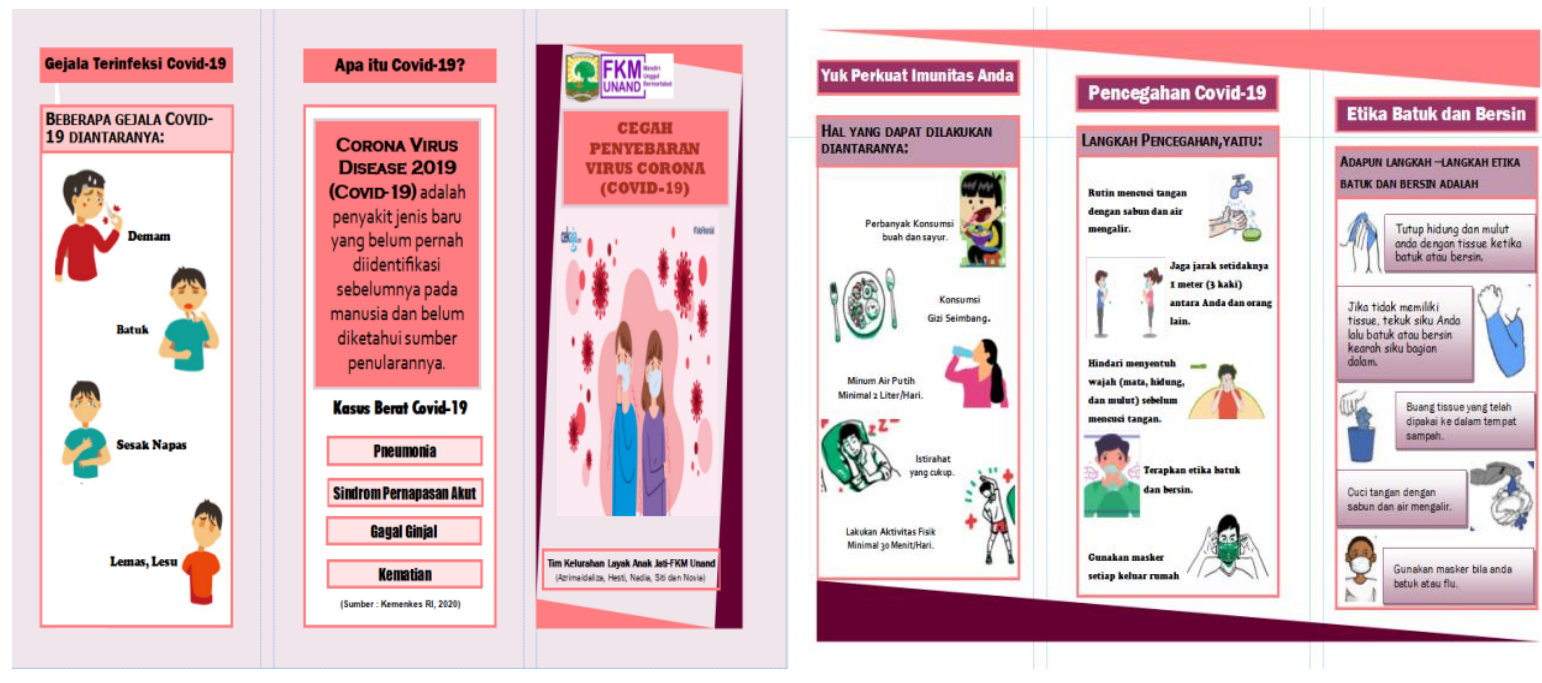

Gambar 1. Media Edukasi mengenai COVID-19

Kegiatan edukasi di Kelurahan Jati tidak hanya berupa edukasi tentang COVID-19 tetapi juga donasi masker sebanyak 400 buah kepada masyarakat khususnya masyarakat yang tidak mampu secara ekonomi yang ada di Kelurahan Jati. Donasi masker terutama diperuntukkan bagi keluarga yang kurang mampu agar dapat melakukan kegiatan sehari-hari, dan berinteraksi dengan masyarakat dapat menggunakan masker, khususnya bagi mereka yang memiliki anggota keluarga yang beresiko tinggi seperti balita, ibu hamil, lansia dan orang yang memiliki penyakit penyerta seperti Asma, Diabetes, Hipertensi, Penyakit Jantung dan lainnya dapat terhindar dari virus ini. Memakai masker merupakan salah satu protokol kesehatan yang diwajibkan oleh pemerintah sebagai upaya untuk menghindari penularan virus COVID-19. Standar masker yang digunakan yaitu masker n-95 dan masker bedah, namun dikarenakan semakin tingginya angka kejadian kasus ini, masker tersebut semakin sulit untuk ditemukan. Sehingga pemerintah menetapkan masker standar SNI (masker n-95 dan masker bedah) hanya diperuntukkan bagi tenaga medis yang bertugas, sedangkan masyarakat umum dianjurkan untuk menggunakan masker kain(7). 
Secara umum, kegiatan edukasi di Kelurahan Jati berjalan dengan lancar dan mendapatkan sambutan yang baik dari Pak Lurah dan aparat kelurahan Jati. Monitoring dan evaluasi kegiatan dilaksanakan melalui informasi yang diperoleh dari Pak Lurah dan masyarakat, salah satunya adalah terkait pemberian masker dan leafleat sudah berjalan baik atau tidak. Pengetahuan dan pemahaman masyarakat terkait COVID-19 dan upaya untuk mencegah agar tidak terkena virus ini diketahui dari informasi yang disampaikan oleh perangkat kelurahan, salah satunya adalah dari penggunaan masker oleh masyarakat pada saat melakukan kegiatan di luar rumah dan mencuci tangan dengan sabun atau menggunakan desinfektan pada saat pergi ke kantor kelurahan atau ke tempat-tempat umum. Selain itu, tim mencantumkan akun resmi sosial media instagram Fakultas Kesehatan Masyarakat Universitas Andalas, yaitu: https://www.instagram.com/p/B_Mrw9FJ3x7/?igshid=lfc4smpzamyw. Pencantuman akun resmi media sosial ini sebagai salah satu media komunikasi antara tim atau institusi pendidikan bidang kesehatan dengan kelurahan dan masyarakat pada kondisi pandemi COVID-19 selain komunikasi melalui telepon. Dokumentasi pelaksanaan kegiatan penyerahan media edukasi dan masker kepada Lurah Jati yang disaksikan perangkat kelurahan seperti terlihat pada Gambar 2 .

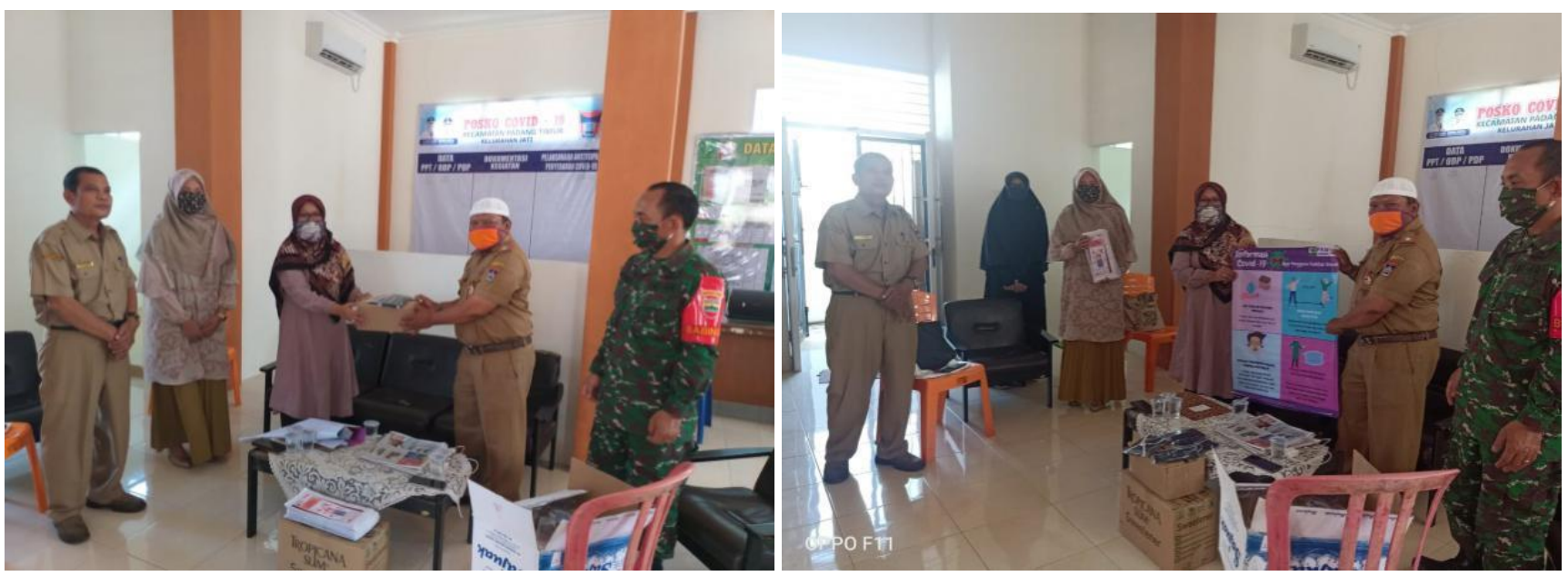

Gambar 2. Penyerahan Masker dan Media Edukasi kepada Lurah Jati

Dalam rangka penyempurnaan dan keberlanjutan kegiatan edukasi masyarakat, tim edukasi berharap ke depannya dapat dilaksanakan edukasi maupun upaya kesehatan lainnya terkait pencegahan COVID-19. Hasil monitoring dan evaluasi kegiatan dapat dijadikan dasar untuk perbaikan kegiatan edukasi berikutnya sehingga meningkatkan efektivitas dan efisiensi kinerja edukasi(8). Kegiatan edukasi selanjutnya antara lain tentang cara mencuci masker kain, aktivitas fisik yang dapat dilakukan dirumah selama wabah dan pengolahan makanan bergizi selama pandemi. Edukasi direncanakan dilaksanakan melalui media yang lebih inovatif dan menarik masyarakat untuk membaca sehingga dapat menambah pengetahuan dan wawasan masyarakat terkait pencegahan penularan COVID-19 serta menerapkannya dalam kehidupan sehari-hari.

\section{KESIMPULAN DAN SARAN}

Kegiatan edukasi berupa edukasi menggunakan media leafleat dan poster serta pemberian donasi masker merupakan salah satu upaya dalam mencegah penyebaran COVID-19. Kegiatan dilaksanakan dengan bekerjasama dengan pemerintah daerah khususnya tingkat kelurahan, yaitu di Kelurahan Jati melalui kegiatan pembinaan oleh institusi pendidikan. Kegiatan edukasi diperuntukkan terutama bagi keluarga yang kurang mampu dengan akses informasi yang 
rendah. Kegiatan berjalan dengan lancar dan mendapat antusias yang baik dari perangkat kelurahan dan masyarakat. Masyarakat diharapkan dapat membaca informasi yang ada sehingga pengetahuan dan pemahaman meningkat serta mau menerapkan perilaku sehat terkait COVID19 dalam beraktivitas sehari-hari khususnya pada saat PSBB. Untuk mencegah penularan COVID-19, perlu monitoring yang dilakukan oleh pihak kelurahan dan RT/RW terhadap perilaku masyarakat.

\section{UCAPAN TERIMA KASIH}

Tim berterima kasih kepada seluruh sasaran edukasi yang telah bersedia meluangkan waktunya terlibat dalam kegiatan edukasi. Selanjutnya kepada Dinas Kesehatan Kota Padang, dan Kelurahan Jati, yang telah memberikan izin dan menerima kegiatan ini dengan baik serta membantu tim dalam melaksanakan kegiatan sehingga dapat berjalan dengan lancar. Selain itu juga kepada staf Fakultas Kesehatan Masyarakat Universitas Andalas yang telah membantu administrasi dan hal lainnya sehingga kegiatan ini dapat berjalan dengan lancar.

\section{DAFTAR PUSTAKA}

1. Susilo AC, et al. Coronavirus Disease 2019: Tinjauan Literatur Terkini. Jurnal Penyakit Dalam Indonesia.7(1).

2. Gugus Tugas Percepatan Penanganan COVID-19. Data Sebaran Virus Corona di Kota Padang Update 23 April 2020 2020. Available from: http://corona.padang.go.id/.

3. Yunus NR, Rezki A. Kebijakan Pemberlakuan Lock Down Sebagai Antisipasi Penyebaran Corona Virus COVID-19 Jurnal Sosial dan Budaya. 2020;7(3).

4. Gugus Tugas Percepatan Penanganan COVID-19. Data Sebaran Virus Corona di Provinsi Sumatera Barat Update 23 April 20202020. Available from: https://corona.sumbarprov.go.id/details/peta_COVID-1919.

5. Azrimaidaliza, Asri R, Handesti M, Lisnayenti Y. Promosi Makanan Sehat dan Bergizi Dalam Upaya Peningkatan Status Gizi Ibu Hamil. Logista Jurnal Ilmiah Edukasi Masyarakat. $2017 ; 1(2)$.

6. Halajur U. Promosi Kesehatan di Tempat Kerja. Jakarta: Wineka Media; 2018.

7. Armiani S, et al. Pelatihan Pembuatan Masker Sebagai Upaya Antisipasi Penyebaran COVID19 di Desa Anyar Kabupaten Lombok Utara. Jurnal Edukasi Undikma. 2020;1(1).

8. Azrimaidaliza, et al. Upaya Peningkatan Kesadaran Masyarakat tentang Tuberkulosis dan Kepatuhan Minum Obat pada Penderita Tuberkulosis di Nagari Pianggu Kabupaten Solok. Buletin Ilmiah Nagari Membangun. 2019;2(1). 